JOURNAL OF PUBLIC HEALTH INOVATION,

VOL. 01 NO.02. JUNI 2021

DOI: $\underline{10.34305 / \text { jphi.v1i2.290 }}$
Ciptaan disebarluaskan di bawah

Lisensi Creative Commons Atribusi-

NonKomersial-BerbagiSerupa 4.0

\title{
POLA MAKAN DENGAN KENAIKAN BERAT BADAN IBU HAMIL TRIMESTER II DAN III DI UPTD PUSKESMAS GARAWANGI KECAMATAN GARAWANGI KABUPATEN KUNINGAN
}

\author{
Merissa Laora Heryanto, Ridha Amalia Sholihati, Ade Siti Maemunah \\ STIKes Kuningan \\ merissalaora123@gmail.com
}

\begin{abstract}
Abstrak
World Health Organization (WHO) mengkonfirmasi bahwa prevalensi Kekurangan Energi Kronik (KEK) pada ibu hamil secara global 35-75\% dimana sebagian besar terjadi pada ibu hamil trimester ketiga. Faktor yang mempengaruhi Kekurangan Energi Kronis, salah satunya yaitu pola makan dan gaya hidup yang tidak sehat. Tujuan penelitian untuk mengetahui hubungan antara pola makan dengan kenaikan berat badan ibu hamil trimester II dan III di UPTD Puskesmas Garawangi. Metode penelitian ini menggunakan rancangan cross sectional. Teknik pengambilan sampel menggunakan accidental sampling dengan jumlah sampel sebanyak 30 responden. Analisa data menggunakan Rank spearman. Hasil analisis bivariat didapatkan ibu yang memiliki pola makan kurang sebagian besar mengalami kenaikan berat badan lebih. Hasil uji statistik didapatkan $p$ value 0 , 000 dan nilai r 0,773. Kesimpulan: terdapat hubungan yang signifikan antara pola makan dengan kenaikan berat badan pada ibu hamil trimester II dan III. Diharapkan Ibu hamil trimester II dan III dapat mengatur pola makan dengan menu gizi seimbang dengan menu yang bervariasi.
\end{abstract}

Kata kunci: Pola Makan, Kenaikan Berat Badan, Ibu Hamil

\section{Pendahuluan}

Permasalahan gizi menjadi penyebab tidak langsung kematian pada ibu dan anak di Indonesia yang sebenarnya kematian karena kekurangan gizi bisa dicegah. Ibu hamil temasuk kedalam kelompok yang berpotensi kekurangan gizi karena terjadi peningkatan kebutuhan gizi dan nutrisi yang akan dimanfaatkan tubuh untuk memenuhi kebutuhan ibu dan janin yang dikandung. Oleh karena itu, bu hamil diwajibkan memiliki keadaan gizi yang cukup sebelum hamil terutama ketika mulai dinyatakan hamil karena gizi dan nutrisi yang didapat akan dimanfaatkan untuk tubuh ibu hamil dan juga 
JOURNAL OF PUBLIC HEALTH INOVATION,

VOL. 01 NO.02. JUNI 2021

DOI: $\underline{10.34305 / \text { jphi.v1i2.290 }}$
Ciptaan disebarluaskan di bawah

Lisensi Creative Commons Atribusi-

NonKomersial-BerbagiSerupa 4.0 janinnya. Seorang ibu yang kekurangan gizi selama masa kehamilan maka bayi yang dikandungnya berpotensi menderita kekurangan gizi (Kristiyanasari, 2010)

\section{World Health Organization (WHO)} mengkonfirmasi bahwa prevalensi Kekurangan Energi Kronik (KEK) pada ibu hamil secara global 35-75\% dimana sebagian besar terjadi pada ibu hamil trimester ketiga, adapun di negara berkembang mencatat $40 \%$ kematian berkaitan dengan kekurangan energi kronis. Kejadian KEK di negara-negara berkembang diantaranya negara Indonesia, India, Bangladesh, Srilangka, Thailand, Nepal, dan Myanmar adalah 15-47\% yaitu dengan BMI $<18,5$. Adapun kejadian yang tertinggi dialami oleh negara Bangladesh yaitu $47 \%$, sedangkan Indonesia mendapati urutan ke empat terbesar setelah India dengan prevalensi $35,5 \%$ dan disusul urutan kelima adalah Thailand dengan prevalensi 15-25\% (WHO, 2015).

Hasil survey pemantauan status gizi (PSG) tahun 2015 dari laporan Kinerja Ditjen Kesehatan Masyarakat menunjukkan angka $13,3 \%$, dimana angka ini masih belum sesuai dengan harapan pencapaian target atau sesuai dengan yang diharapkan yaitu $24,2 \%$. Sementara itu pada tahun 2016 didapatkan sebesar 16,2, meskipun demikian angka ini berada di bawah target yang diinginkan yaitu 22,7\%. (Kementerian Kesehatan, 2016).

Keadaan ibu hamil KEK berpotensi menurunkan tenaga yang dapat membantu kelancaran proses persalinan sehingga dapat menyebabkan terjadinya kematian pada janin seperti keguguran, lahir kurang bulan, cacat pada bayi, Bayi Berat Lahir Rendah (BBLR) sampai berpotensi terjadinya kematian bayi. Ibu hamil dengan KEK dapat mengakibatkan terganggunya tumbuh kembang janin seperti terjadinya kejadian stunting, kecacatan otak dan metabolisme yang mengakibatkan penyakit menular di usia dewasa (Muliarini, 2010).

Kekurangan energi kronis dipengaruhi oleh berbagai faktor, diantaranya pola makan dan gaya hidup yang tidak sehat. Untuk memperoleh pengaruh yang lebih baik dari pola makan ibu hamil, perlu memperhatikan beberapa prinsip yaitu jumlah yang dikonsumsi lebih banyak, kualitas makanan lebih baik, selain itu makanan harus bergizi seimbang. Strategi untuk mendapatkan kecukupan zat gizi menurut (Nugraini, 2013) memaparkan bahwa dalam bentuk piring makanku yang dibagi empat bagian yang terdiri dari $1 / 2$ makanan mengandung karbohidrat, 1/4 makanan mengandung protein, 1/4 kelompok sayuran dan 1/4 lagi buah-buahan. Adapun menu ibu hamil yang seimbang setara dengan nasi/pengganti 5-6 piring, lauk hewani 4- 
JOURNAL OF PUBLIC HEALTH INOVATION,

VOL. 01 NO.02. JUNI 2021

DOI: $\underline{10.34305 / \text { jphi.v1i2.290 }}$

5 potong, lauk nabati 3-4 potong, sayuran 2-3

mangkuk, buah-buahan 3 potong dan dianjurkan minum 8-12 gelas/hari (Prastiwi, 2015).

Berdasarkan uraian diatas, peneliti tertarik melakukan penelitian untuk mengetahui hubungan pola makan dengan kenaikan berat badan ibu hamil trimester II dan III di UPTD Puskesmas Garawangi Kabupaten Kuningan Tahun 2019.

\section{Hasil Penelitian}

Hubungan antara Pola Makan dengan Kenaikan Berat Badan Ibu Hamil Trimester II dan III di UPTD Puskesmas Garawangi Kecamatan Garawangi Kabupaten Kuningan Tahun 2019

Tabel 1 Distribusi Frekuensi Responden

\begin{tabular}{|c|c|c|}
\hline Variabel & Frekuensi (n) & Persentase $(\%)$ \\
\hline \multicolumn{3}{|l|}{ Pola Makan } \\
\hline Baik & 11 & 36,7 \\
\hline Cukup & 4 & 13,3 \\
\hline Kurang & 15 & 50 \\
\hline \multicolumn{3}{|l|}{ Kenaikan Berat Badan } \\
\hline Kurang & 1 & 3,3 \\
\hline Normal & 14 & 46,7 \\
\hline Lebih & 9 & 30 \\
\hline Obesitas & 6 & 20 \\
\hline
\end{tabular}

Ciptaan disebarluaskan di bawah Lisensi Creative Commons Atribusi-

NonKomersial-BerbagiSerupa 4.0 Internasional.

\begin{abstract}
Penelitian ini menggunakan metode crosssectional, dilakukan tahun 2019 di UPTD Puskesmas Garawangi Kecamatan Garawangi Kabupaten Kuningan pada ibu hamil yang sedang melakukan kunjungan ANC di UPTD Puskesmas dengan menggunakan accidental sampling yang berjumlah 30 responden. Pengumpulan data dengan menggunakan kuesioner. Analisis bivariat dengan Uji Rank spearman.

Metode
\end{abstract}


JOURNAL OF PUBLIC HEALTH INOVATION,

VOL. 01 NO.02. JUNI 2021

DOI: $\underline{10.34305 / \text { jphi.v1i2.290 }}$
Ciptaan disebarluaskan di bawah

Lisensi Creative Commons Atribusi-

NonKomersial-BerbagiSerupa 4.0

Internasional.
Pada tabel 1 dapat diketahui bahwa dari 30 responden, sebagian besar responden memiliki pola makan kurang baik sebanyak 15 orang
(50\%) dan sebagian besar Ibu hamil mengalami kenaikan berat badanya normal sebanyak 14 orang $(46,7 \%)$.

Tabel 2 Hubungan antara Pola Makan dengan Kenaikan Berat Badan Ibu Hamil Trimester II dan III di UPTD Puskesmas Garawangi Kecamatan Garawangi Kabupaten Kuningan Tahun 2019

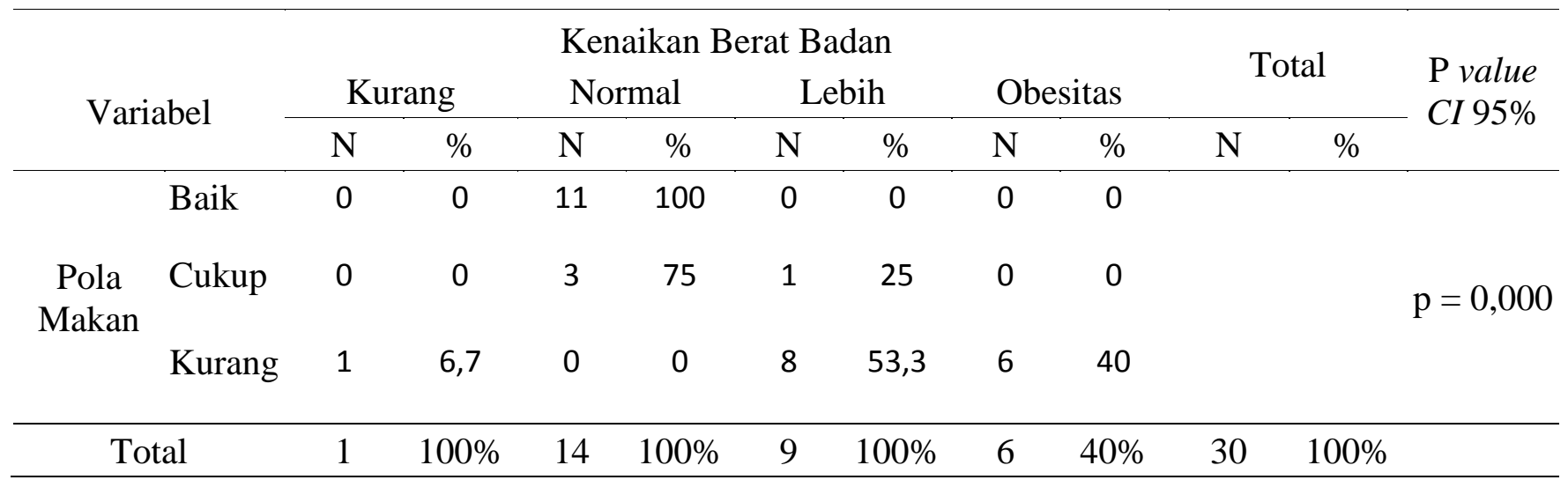

Berdasarkan tabel 2 dapat diketahui bahwa dari 11 responden dengan pola makan baik seluruhnya mengalami kenaikan berat badan normal sebanyak 11 responden $(100 \%)$, dari 4 responden dengan pola makan cukup sebagian besar mengalami kenaikan berat badan normal sebanyak 3 responden (75\%) dan dari 15 responden dengan pola makan kurang sebagian besar mengalami kenaikan berat badan lebih sebanyak 8 responden $(53,3 \%)$. Hasil analisis didapatkan nilai $p=0,000<0,05$ dengan demikian ada hubungan antara pola makan dengan kenaikan berat badan ibu hamil trimester II dan III. Nilai 0,773 merupakan keeratan hubungan yang kuat dengan arah positif, artinya semakin baik pola makannya maka semakin normal kenaikan berat badan ibu hamil trimester II dan III.

\section{Pembahasan}

Berdasarkan hasil penelitian diketahui bahwa jika dibandingkan antara pola makan yang baik dengan yang kurang baik ternyata pola makan kurang baik lebih besar daripada pola makan ibu hamil yang baik. Sunita (2013), memaparkan bahwa ibu hamil trimester II pola makannya 3x sehari ditambah selingan, adapun pada ibu hamil trimester III sesuaikan dengan 
JOURNAL OF PUBLIC HEALTH INOVATION,

VOL. 01 NO.02. JUNI 2021

DOI: $\underline{10.34305 / \text { jphi.v1i2.290 }}$
Ciptaan disebarluaskan di bawah

Lisensi Creative Commons Atribusi-

NonKomersial-BerbagiSerupa 4.0 keadaan berat badan ibu, perbanyak makan sayur dan buah untuk mencegah terjadinya sembelit (Sunita, 2013). Hal ini sejalan dengan teori dari Nugraini (2013) yang menyatakan bahwa strategi untuk mendapatkan kecukupan zat gizi yaitu dalam bentuk piring makanku yang dibagi empat bagian yang terdiri dari $1 / 2$ makanan mengandung karbohidrat, 1/4 makanan mengandung protein, $1 / 4$ kelompok sayuran dan 1/4 lagi buah-buahan (Nugraini, 2013). Kasdu (2015) menambahkan bahwa pola makan yang sehat pada ibu hamil yaitu patuhi jadwal makan yaitu 3x dengan cemilan 2 kali sehari dengan menu gizi seimbang, jangan lupa sarapan, kurangi makanan yang mengandung junk food dan kafein (Kasdu, 2015). Menurut (Paath, 2014), beberapa hal yang perlu dihindari dalam menerapkan pola makan yang sehat ibu hamil yaitu harus manghindari jenis makanan yang mengandung pengawet, ibu hamil juga harus mengurangi porsi makanan yang berkalori tinggi, mengurangi makanan yang berlemak tinggi, menghindari daging, ikan, ayam dan sumber protein lainnya yang tidak dimasak dengan baik atau yang tidak matang dan hindari makanan ataupun minuman yang mengandung alkohol meskipun jumlahnya sedikit. Sulistyoningsih mengemukakan bahwa lingkungan, ekonomi dan kesenangan mempengaruhi terbentuknya pola makan (Sulistyoningsih, 2015).

Penelitian Hidayati (2011) memaparkan bahwa pantangan makanan dan penyakit infeksi terhadap Risiko Kurang Energi Kronis (KEK) menunjukkan hasil dari 108 responden mayoritas tidak sesuai pada pola konsumsi makanan popok $(57,4 \%)$, lauk hewani $(53,7 \%)$, sayuran $(60,2 \%)$ dan buah buahan $(68,5 \%)$. Sedangkan pola konsumsi lauk nabati mayoritas sesuai anjuran (67,6\%) (Hidayati, 2011).

Pola makan kurang baik dalam hal ini tidak sesuai anjuran, dimana pola makan yang baik yaitu pola makan yang mencakup gizi seimbang diantaranya mengandung karbohodrat, protein, sayuran dan buah-buahan dengan jadwal makan yaitu 3x dengan cemilan 2 kali sehari. Menurut hasil kuesioner pada pola makan ibu hamil trimester II, pola makan yang kurang baik yaitu pada jadwal mayoritas tidak sesuai anjuran. Hal ini terlihat dari hasil kuesioner pada soal nomor 3 hanya sebagian kecil $(47 \%)$ yang menjawab selalu mengkonsumsi sayur atau buah sebanyak 3 kali sehari, mereka lebih banyak mengkonsumsinya dalam waktu seminggu sekali, andaikan tiap hari itu juga hanya sekali tapi hanya sewaktu-waktu dengan alasan bosan dan tergantung adanya keinginan. Khususnya untuk buah, mereka sama sekali jarang mengkonsumsinya dengan alasan mahal dan 
JOURNAL OF PUBLIC HEALTH INOVATION,

VOL. 01 NO.02. JUNI 2021

DOI: $\underline{10.34305 / \text { jphi.v1i2.290 }}$
Ciptaan disebarluaskan di bawah

Lisensi Creative Commons Atribusi-

NonKomersial-BerbagiSerupa 4.0 dalam pola makan sehari-hari mengkonsumsi buah tidak dijadikan sebagai suatu kebiasaan, makanya ibu cenderung mengkonsumsinya seminggu sekali atau jika ada keinginan. Menurut mereka makanan sayur dan buah banyak ibu konsumsi pada saat kehamilan trimerter I dengan alasan menghindari rasa sebel dan anjuran dari tenaga kesehatan. Justru pada trimester II mereka banyak mengkonsumsi makanan cepat saji seperti pizza, bakso, gorengan dan sebagainya dengan alasan karena keinginan bayi dalam kandungannya dan sudah menjadi kebiasaan, hal ini seolah-olah sebagai balas dendam karena pada kehamilan trimester I ibu susah makan. Begitu juga dalam mengkonsumsi vitamin hampir seluruhnya ibu hamil trimester II tidak mengkonsumsinya, kondisi ini dapat dilihat dari hasil kuesioner pada soal nomor 8 didapatkan hanya $7 \%$ ibu yang mengkonsumsi vitamin, adapun yang dikonsumsi yaitu tablet tambah darah dengan alasan sekarang saja sudah nafsu makan, apalagi jika ditambah dengan mengkonsumi suplemen nantinya bisa mempengaruhi bayi dalam kandungannya menjadi besar dan ibu menjadi gemuk.

Adapun pola makan ibu yang baik yaitu mayoritas ibu melakukan kebiasaan sarapan pagi, hal ini dapat dilihat dari hasil kuesioner pada soal nomor 1 didapatkan $93 \%$ ibu selalu melakukan sarapan pagi dengan alasan lapar. Pola makan yang baik lainnya yaitu mengkonsumsi protein, sesuai dengan hasil kuesioner pada soal nomor 9 didapatkan $93 \%$ ibu membiasakan untuk mengkonsumsi makanan yang mengandung protein 3 kali sehari seperti ikan, daging dan susu dengan alasan agar bayi dalam kandungannya sehat dan cerdas.

Selanjutnya pada ibu hamil trimester III sebagian ibu berusaha untuk mengendalikan berat badan dengan membatasi asupan makanan dengan cara tidak makan 3 kali sehari atau lebih sesuai dengan hasil kuesioner pada soal nomor 11 mayoritas menjawab berusaha untuk mengendalikan berat badan sebanyak $87 \%$, akan tetapi pada soal nomor 12 , banyak ibu mengatakan ya untuk mengkonsumsi makanan tambahan dengan alasan karena adanya rasa lapar menjadikan ibu cenderung banyak ngemil bahkan sampai malam dengan alasan agar dapat tidur dengan nyenyak, sehingga ditemukan hanya $47 \%$ ibu yang memembatasi ngemil hanya sampai 3 kali sehari dan malam hari ibu tidak melakukannya karena mengikuti anjuran bidan agar bayi dalam kandungannya tidak terlalu besar.

Pola makan yang kurang baik pada trimester III juga yaitu dalam mengkonsumsi makanan cepat saji maupun makanan berlemak, 
JOURNAL OF PUBLIC HEALTH INOVATION,

VOL. 01 NO.02. JUNI 2021

DOI: $\underline{10.34305 / \text { jphi.v1i2.290 }}$
Ciptaan disebarluaskan di bawah

Lisensi Creative Commons Atribusi-

NonKomersial-BerbagiSerupa 4.0 mereka cenderung mengkonsumsi bisa lebih dari 2 kali dalam sehari, sesuai dengan hasil kuesioner pada soal nomor 17, 18 dan 19 hanya $40-47 \%$ ibu yang menjaga asupan makana tersebut. Alasan yang diutarakan responden bermacam-macam, dimulai dari adanya alasan keinginan anak, karena menjadi suatu kebiasaan juga karena mumpung ada uang untuk membelinya. Berdasarkan penjelasan tersebut, peneliti berasumsi bahwa kondisi ekonomi, lingkungan yang sudah terbiasa mengkonsumsi makanan tertentu sehingga menjadi kebiasaan dan adanya kesenangan terhadap makanan menjadikan faktor ibu mengkonsusmsi makanan dengan pola makan yang kurang baik.

Berdasarkan hasil penelitian didapatkan bahwa dari 30 responden berat badan ibu hamil yang normal lebih banyak dibandingkan dengan berat badan kurang, lebih dan obesitas. Guyton (2013) menuliskan bahwa bertambahnya berat badan ibu ketika masa kehamilan terdiri dari dua bagian utama, yakni janin dan jaringan ibu (Guyton, 2013). Pertambahan berat badan ibu hamil pada trimester III dipengaruhi oleh pertambahan berat janin yaitu penimbunan lemak tubuh dan perkembangan otak janin. Kristiyanasari (2010:51), mengatakan bahwa kenaikan berat badan trimester I kurang lebih 1 $\mathrm{kg}$, trimester II $3 \mathrm{~kg}$, dan trimester III $6 \mathrm{~kg}$. Ratarata kenaikan berat badan selama kehamilan yaitu $11,3 \mathrm{~kg}$ - 15,9 kg. Arisman (2014) menuliskan, ada beberapa faktor yang mempengaruhi kenaikan berat badan pada kehamilan yaitu makan terlalu banyak dan selera makan yang besar (Arisman, 2014). Sesuai dengan hasil penelitian (Desy, 2014), menunjukkan bahwa dari 86 responden mayoritas penambahan berat badannya normal sebanyak $80,2 \%$. Berdasarkan hasil penelitian, mayoritas berat badan ibu hamil berada pada kategori normal sisanya dengan berat badan lebih, obesitas dan kurang. Sebelumnya ibu hamil dari 30 responden berat badan ibu dengan kategori kurang sebanyak 5 responden (16,7\%), normal sebanyak 18 responden (60\%), lebih sebanyak 5 responden $(16,7 \%)$ dan obesitas sebanyak 2 responden $(6,7 \%)$. Adapun pada saat dilakukan penelitian ternyata mengalami perubahan dimana berat badan dalam kategori kurang mejadi sebanyak 1 responden $(3,3 \%)$, normal sebanyak 14 responden (46,7\%), lebih sebanyak 9 responden (30\%) dan obesitas sebanyak 6 responden (20\%). Dengan demikian dapat diketahui bahwa hampir seluruhnya responden mengalami kenaikan berat badan. Hal ini disebabkan oleh adanya pertambahan berat badan janin dan penimbunan lemak dalam tubuh ibu, yang pada akhirnya menimbulkan berat badan ibu meningkat dari berat badan sebelumnya. Biasanya pada ibu trimester II dan 
JOURNAL OF PUBLIC HEALTH INOVATION,

VOL. 01 NO.02. JUNI 2021

DOI: $\underline{10.34305 / \text { jphi.v1i2.290 }}$
Ciptaan disebarluaskan di bawah

Lisensi Creative Commons Atribusi-

NonKomersial-BerbagiSerupa 4.0

Internasional.
III mengalami selera makan yang baik dibadingkan dengan ibu hamil trimester I, secara alamiah keinginan untuk selalu makan karena selain untuk kebutuhan ibunya sendiri juga untuk pertumbuhan janin yang berada di dalam kandungan ibu. Secara garis besar kenaikan berat badan ibu dalam kondisi normal, akan tetapi perlu diberi penjelasan pada responden bahwa perlu menjaga makanan dengan menu gizi seimbang agar dan hindari makanan berlemak dan karbohidrat tinggi karena dikhawatirkan dapat mengakibatkan bayi dalam kandungan ibu terlalu besar yang nantinya bayi dilahirkan tidak bisa secara normal.

Berdasarkan hasil dari penelitian didapatkan 11 responden dengan pola makan baik mengalami kenaikan berat badan yang normal dan dari 15 responden dengan pola makan kurang sebagian besar mengalami kenaikan berat badan lebih sebanyak 8 responden. Hasil analisis didapatkan nilai $p$ $=0,000<0,05$ dengan demikian dapat diartikan ada hubungan antara pola makan dengan kenaikan berat badan ibu hamil trimester II dan III. Nilai 0,773 merupakan korelasi kuat dengan arah positif, artinya semakin baik pola makannya maka semakin normal kenaikan berat badan ibu hamil trimester II dan III.
Sulistyoningsih (2015), mengatakan bahwa mengatakan bahwa pola makan yang baik selalu mengacu kepada gizi seimbang. Pemasukan makanan ibu hamil trimester II nafsu makan ibu biasanya sudah meningkat (Sulistyoningsih, 2015). Begitu juga pada trimester III, menurut Manuaba (2010) umumnya nafsu makan ibu sangat baik, dan ibu sering merasa lapar. Pada masa ini hindari makan berlebihan sehingga berat badan tidak naik terlalu banyak. Adapun makanan yang harus banyak dikonsumsi yaitu makanan yang mengandung sumber zat pembangun (protein hewani dan nabati) dan pengatur (sayur dan buah) (Manuaba, 2010).

Arisman (2014) mengatakan bahwa memakan makanan yang berlebihan merupakan faktor kenaikan berat badan pada ibu hamil. Memasuki trimester ketiga kondisi selera makan ibu hamil mulai membaik dan meningkat sehingga dapat menyebabkan ibu hamil kehilangan control makannya sehingga bertambahnya berat badan ibu hamil (Arisman, 2014). Berat badan selama kehamilan dipengaruhi oleh beberapa faktor, bukan hanya berapa banyak yang diamakan ibu hamil, akan tetapi kualitas makanan yang dimakan juga mempengaruhi, sehingga menyebabkan kelebihan berat badan. Disamping itu selera makan yang terlalu banyak ditambah dengan 
JOURNAL OF PUBLIC HEALTH INOVATION,

VOL. 01 NO.02. JUNI 2021

DOI: $\underline{10.34305 / \text { jphi.v1i2.290 }}$
Ciptaan disebarluaskan di bawah

Lisensi Creative Commons Atribusi-

NonKomersial-BerbagiSerupa 4.0

Internasional. kurangnya olah raga, dapat meningkatkan terjadinya kenaikan berat badan.

Responden yang memiliki pola makan baik sebanyak 11 responden $(36,7 \%)$ dengan kenaikan berat badan normal. Hal ini menunjukan bahwa pola makan baik mempengaruhi kenaikan berat badan yang normal karena pada dasarnya ibu hamil mengetahui akan pentingnya menjaga pola makan agar tidak kurang dan berlebihan berat badan.

Responden yang memiliki pola makan cukup sebanyak 4 responden (13,3\%) dengan kenaikan normal sebanyak 3 responden dan 1 responden memiliki kenaikan berat badan yang lebih. Hal ini terdapat 1 responden yang kenaikan berat badan lebih karena memang pengetahuan ibu yang kurang sehingga tidak mengetahui tentang kenaikan berat badan yang normal dan tidak mengontrol pola makan.

Responden yang memiliki pola makan kurang sebanyak 15 responden (50\%) dengan kenaikan lebih sebanyak 8 responden dan 6 orang mengalami kenaikan berat badan sampai obesitas. Hal ini karena pola makan ibu tidak pernah teratur dan sering makan yang berserat tinggi sehingga mempengaruhi ibu dan menaikan berat badan yang berlebih. Hal ini Sesuai dengan penelitian dari Harti (2016), bahwa terdapat hubungan antara pola makan makanan pokok selama kehamilan dengan penambahan berat badan, artinya jika pola makan makanan pokok selama masa kehamilan meningkat maka nilai penambahan berat badan akan meningkat juga (Budhi Harti et al., 2016).

\section{Kesimpulan}

Terdapat hubungan antara pola makan dengan kenaikan berat badan ibu hamil trimester II dan III dengan nilai $p=0,000$.

Bagi Ibu hamil trimester II dan III diharapkan dapat mempertahankan pola makan dengan menu gizi seimbang dengan menu yang bervariasi, mengurangi makanan cepat saji, makanan yang terlalu manis dan berlemak agar kenaikan berat badan dalam kondisi normal sehingga didapatkan status gizi ibu dalam keadaan baik.

\section{Referensi}

Arisman, M. B. (2014). Buku Ajar Ilmu Gizi dalam Daur Kehidupan (2 ed.). Penerbit Buku Kedokteran EGC.

Budhi Harti, L., Kusumastuty, I., \& Hariadi, I. (2016). Hubungan Status Gizi dan Pola Makan terhadap Penambahan Berat Badan Ibu Hamil (Correlation between Nutritional Status and Dietary Pattern on Pregnant Mother's Weight Gain). Indonesian Journal of Human Nutrition, 
JOURNAL OF PUBLIC HEALTH INOVATION,

VOL. 01 NO.02. JUNI 2021

DOI: $\underline{10.34305 / \text { jphi.v1i2.290 }}$

$3(1)$, $54-62$. https://doi.org/10.21776/ub.ijhn.2016.003. suplemen.6

Desy, A. F. (2014). Hubungan Pertambahan Berat Badan Ibu Hamil Trimester II dengan Berat Bayi Lahir di Kabupaten Semarang [Universitas Muhammadiyah Surakarta]. http://eprints.ums.ac.id/29465/

Guyton, A. (2013). Buku Ajar Fisiologi Kedokteran. Kedokteran EGC.

Hidayati, F. (2011). Hubungan Antara Pola Konsumsi, Penyakit Infeksi Dan Pantang Makanan Terhadap Risiko Kurang Energi Kronis (Kek) Pad Ibu Hamil Di Puskesmas Ciputat Kota Tangerang Selatan Tahun 2011. In UIN Syarif Hidayatullah (Vol. 1).

Kasdu, D. (2015). Pengantar Kuliah Obstetri. Puspa Suara.

Kementerian Kesehatan, R. (2016). Buku Kesehatan Ibudan Anak. Kemenkes RI.

Kristiyanasari, W. (2010). Gizi Ibu Hamil. Nuha Medika.
Ciptaan disebarluaskan di bawah Lisensi Creative Commons Atribusi-

NonKomersial-BerbagiSerupa 4.0 Internasional.

Manuaba, I. B. (2010). Ilmu Kebidanan Penyakit kandungan dan KB untuk Pendidikan Bidan. Kedokteran EGC.

Muliarini, P. (2010). Pola Makan dan Gaya Hidup Sehat Selama Kehamilan. Nuha Medika.

Nugraini, S. (2013). Ilmu Gizi 2. Direktorat Pembinaan SMK, 1-254.

Paath, E. (2014). Gizi dalam Kesehatan Reproduksi. Kedokteran EGC.

Prastiwi. (2015). Pola Makan Sehat dan Gizi Remaja. Nobel Edumedia.

Sulistyoningsih, H. (2015). Gizi Untuk Kesehatan Ibu dan Anak. Graha Ilmu.

Sunita. (2013). Prinsip Ilmu Gizi. Gramedia Pustaka Utama.

WHO. (2015). Regional Nutrition Strategy: Addressing malnutrition and micronutrient deficiencies. 